\title{
Contemporary Judeo-Spanish Poetry for Young Readers
}

\section{Agnieszka August-Zarębska ${ }^{1}$}

Accepted: 19 August 2021 / Published online: 18 October 2021

(c) The Author(s) 2021

\begin{abstract}
This article presents contemporary Judeo-Spanish poetry for children in the context of the postvernacular mode (when the language is not used any more in everyday communication) of the language. It discusses the poetry collections of three authors who have published Judeo-Spanish poems in the twenty-first century: Ada GattegnoSaltiel, Avner Perez, and Sarah Aroeste, as well as the project Yeladino, which is an anthology of Judeo-Spanish translations of Hebrew poems. It analyses the books and projects in terms of their subject matter, language, and poetic devices, as well as the relation of some of them with music, theatre-music performance, and educational activities. The paper raises the question of audience of this poetry, allowing for the fact that nowadays there are no children learning Judeo-Spanish as their first language, and that the language itself is considered severely endangered. The paper states the presence of the dual address in these books, i.e. to children and adults, both on the level of implied and real audience.
\end{abstract}

Keywords Judeo-Spanish · Postvernacular language · Poetry for children · Audience $\cdot$ Contemporary Judeo-Spanish literature

\section{Introduction}

Judeo-Spanish was the vernacular language of Sephardic Jews, exiled from the Iberian Peninsula in the late fifteenth century. After the exile, it developed in the Turkish-Balkan and North African Diaspora and was widely used in speech and writing until WWII, when the Holocaust decimated the community using it. From the beginning of the twentieth century, however, the dominant role of the language was gradually reduced and the pace of its shrinkage varied from country to country of the former Ottoman Empire, and differed in different spheres of life. In Yugoslavia, for example, it was largely eliminated from the public sphere and from the Jewish

Agnieszka August-Zarębska

agnieszka.august-zarebska@uwr.edu.pl

1 Taube Department of Jewish Studies, University of Wrocław, Ul. Św. Jadwigi 3/4,

50-266 Wrocław, Poland 
press in the 1920s and 1930s, whereas in Greece, Macedonia, and Turkey it still remained the language of the Jewish press, literature, and culture. After WWII, it still persisted as the language of everyday communication in mono-ethnic Sephardic populations, e.g. in Turkey, Israel, and South America. Yet, each following decade brought further social changes leading to the displacement of Judeo-Spanish in favour of the language of the particular country, and, as a result, to its extinction (see Díaz-Mas, 2020, pp. 111-127).

By the 1970s, it had become clear to researchers and to Sephardim themselves that the language was in serious danger of extinction (Sephiha, [1977] 1991). Since the end of that decade, a return to Judeo-Spanish can be observed, yet with its users' awareness that it is becoming a thing of the past and that the last moment has come to take action to document and save it. This phenomenon has been referred to as the revival, or arrebivimiento, of the language and its literature, the latter being mainly limited to the genre of poetry (Romero, 2008, p. 188). This included the reintroduction of the language into print - for example, in the magazine Aki Yerushalayim and in new book publications. In Israel, an attempt was made to teach the language in one high school, and Judeo-Spanish as well as its literature were incorporated into university program curricula in Europe, Israel, and the United States. Language textbooks and dictionaries were produced to meet the needs of the subjects taught. Arrebivimiento activists in various countries saw in the development of internet communication an opportunity for a revival of the language that no longer functioned naturally. They created discussion fora, e.g., Ladinokomunita, that connected users and adepts of the language living in distant places. The flourishing of contemporary Judeo-Spanish poetry is one manifestation of arrebivimiento.

For three decades, the poetry that emerged was addressed to adult readers, since the narrow audience that was able to read it was mainly mature and elderly people. Therefore, it may seem surprising that an edition, consisting of four small books, was published in 2010 that identified children as one of its target audiences in its title and preface: Multikolor. Poemas para chikos i grandes (Multikolor. Poems for Small and Big) by Ada Gattegno-Saltiel and Una Torre en Yerushalayim (A Tower in Jerusalem) by Avner Perez. At the same time, according to the UNESCO Atlas of the World's Languages in Danger, Judeo-Spanish (under the name Judezmo) was already classified as severely endangered, which means that "the language is spoken by grandparents and older generations; while the parent generation may understand it, they do not speak it to children or among themselves" (2017). Based on that, the questions arise: Whom were these poems written for? What were the publishers' motivations and objectives? Does this literature really reach a young audience? If yes, what is its function? These questions will be tackled below in this paper (see also Martín-Ortega and August-Zarębska, 2017). 


\section{Judeo-Spanish in its Postvernacular Mode}

From today's perspective, the uses of language in arrebivimiento, especially relying on publishing in that language, can be described as postvernacular practices. A clarification of how this term functions in Yiddish literature has been provided by Jeffrey Shandler in Adventures in Yiddishland. Postvernacular Language and Culture (2006):

In semiotic terms, the language's primary level of signification - that is, its instrumental value as a vehicle for communicating information, opinions, feelings, ideas - is narrowing in scope. At the same time its secondary, or metalevel of signification - the symbolic value invested in the language apart from the semantic value of any given utterance in it - is expanding. This privileging of the secondary level of signification of Yiddish over its primary level constitutes a distinctive mode of engagement with the language that I term postvernacular Yiddish (2006, p. 4).

In a postvernacular mode, the choice of using a language in a particular context becomes even more important. Some practices that were present in the vernacular speech community, such as writing, reading, performing, language learning, or simply speaking it, gain a novel and transformed meaning. New ways of engaging with the language appear, while some others - which existed earlier but had a peripheral position - move towards the centre. Many of them do not require fluency in the language or allow only its vestigial knowledge (Shandler, 2006, p. 43). Like any post-phenomenon, the term "post-vernacular" refers chronologically to a condition that occurred after the era of "vernacularity", or implies a transience of the main assumptions of "vernacularity." The term "postvernacularity" has recently also been applied to the contemporary situation of Judeo-Spanish, specifically to its presence on the internet, which has opened new opportunities to communicate and learn it (Brink-Danan, 2011; August-Zarębska and Paprocka, 2021).

Contemporary Sephardic poetry is a postvernacular phenomenon primarily because of the very choice of someone's writing in Judeo-Spanish, which is not their first or main language. Only a few of the oldest members who published poems in the times of arrebivimiento had the experience of living in a community that communicated primarily in Judeo-Spanish. Most of the others remembered it from childhood, from conversations between some family members, or from interactions among the older generation. The issue of the authors' motivations can be complex, but amongst them are always: the extension of the existence of the language, its development as a literary language, the commemoration of it, and of its culture. What is important is that the authors, through their writing, want to get in contact with their language of origin. ${ }^{1}$ As to the readers, in the late 1970s and early 1980 s, there was no longer a natural audience for their poems. Both the authors and the readers regarded themselves as a community centered around the preservation of the

\footnotetext{
1 Information obtained directly from an Israeli poet of Judeo-Spanish language Margalit Matitiahu.
} 
language and its literature. At the same time, a system of symbolic practices associated with belonging to this community was taking shape.

Contemporary Judeo-Spanish children's poetry is part of arrebivimiento. Whom, then, was it written for, given that the younger generation hardly use Sephardic language? Ada Gattegno-Saltiel and Avner Perez, the authors of the first collection mentioned above, brought up this issue in the preface entitled Un Rekolio de Poemas Para Ninyos (A Collection of Poems for Children). ${ }^{2}$ They say that their main objective was to work on the expressive possibilities of the language and to try to meet the genre requirements of poems for children. The main target group was then the devotees of Judeo-Spanish, "who could enjoy these works, provided that they have been well-written" (El Instituto Maale Adumim para la dokumentasion de la lengua djudeo-espanyola (ladino) y su kultura, 2009). ${ }^{3}$ This is the same audience to which adult poetry and other publications in that language, e.g. Aki Yerushalayim magazine, ${ }^{4}$ were addressed.

The second target group was children, yet it should be noted that an older generation, grandparents and parents, had to be intended as the intermediary in the reception of these texts. Thus, the question arises whether the issue of dual addressee in the poetry of Perez and Gattegno-Saltiel is identical to the presence of dual reader in many other children's books (see Wall, 1991, p. 20-22; Bullen \& Nichols, 2011, p. 215-217; Cheetham, 2013). Although the basic definition of children's genre points to the child-intended audience as its characteristic (Lerer, 2008, p. 2), it is also known that "[i]f books are to be published, marketed and bought, adults first must be attracted, persuaded and convinced" (Wall, 1991, p. 13). The adult is a recipient, first of all, at the level of perusing the publisher's offer and choosing a book, but also later, when reading it aloud to preschool children or primary education pupils. Indeed, in the case of Judeo-Spanish poetry, there is also an additional aspect on the part of an adult. Access to it depends not only on the ability to read, but above all on the knowledge of Judeo-Spanish itself. The Hebrew versions of the poems were supposed to be an additional aid for both groups, and this in turn shows that the majority of potential audiences were to be Israelis, Hebrew-speaking ones. Presumably, the Hebrew version could be sometimes read by a school child. Yet, when dealing with Judeo-Spanish poems, the adult recipient is necessary not only as an intermediary between the child and the text, but also between the child and the language itself.

As to the number of languages in Perez's and Gattegno-Saltiel's volumes, it should be noted that a feature of many contemporary Judeo-Spanish publications belonging to the postvernacular mode of the language, is the coexistence of other languages. Sometimes they serve a purely marketing function: publishing and sales information is given in Judeo-Spanish in addition to Spanish, English, or Hebrew.

\footnotetext{
2 Although the name of the author of the preface is not given, it is apparently Perez, who was also the editor. In 2009, before finishing the printed edition, Perez published the on-line version of the project available on the site of Maale Adumim Institute for the Documentation of Judeo-Spanish Language (Ladino) and its Culture and the poems may still be found there. In the on-line edition, the preface is entitled Dos livros de poezias para ninyos en ladino (Two Books of Poetry for Children in Ladino, 2009).

3 All translations into English are made by the author.

${ }^{4}$ Aki Yerushalayim had already published selected texts from the collection.
} 
Judeo-Spanish seems to be a barrier to the distribution process (advertising, sales, classification in catalogues and databases). However, often such support is also needed at the reading level, i.e., dictionaries, glossaries, or parallel versions of the text in another language. In its current phase of existence, the language is not independent and self-sufficient.

\section{Multikolor-Nursery Rhymes for Grandparents and Grandchildren}

The collection Multikolor. Poemas para chikos i grandes by Gattegno-Saltiel was issued in an unusual form: in a cardboard box that contained four small books on coated paper measuring $16 \times 12 \mathrm{~cm}$ : two books with, respectively, the Judeo-Spanish and Hebrew versions of Multikolor, and two with both language versions of Avner Perez's Una Torre en Yerushalayim, along with an electronic version on CD. The prefaces to the volumes, also in both languages, are on separate sheets inserted in the box and contain information about, among other things, the intentions of the authors. Beside its format, it differs from other editions of Judeo-Spanish poetry by the presence of colour. The pages have colourful photos and pictures, while in Multikolor even the letters in some poems are coloured. These elements distinguish them from other poetry volumes published by Yeriot, and even more broadly from any Judeo-Spanish adult books of the past four decades. The layout of the GattegnoSaltiel's and Perez's small books suggests that they were planned for a rather different audience than other poetry books. However, it also differs in aesthetics from the layout of children's literature published at the same time in Israel and other countries. This reveals that the publisher did not probably have the means to adjust the material form of the book to the dominant trends in the market. Indeed, this album had a very modest print run and little distribution.

The poems in Gattegno-Saltiel's volume have been described as "nursery rhymes". Indeed, they are short, rhythmic, and rhyming compositions that use simple images from the natural world or from a child's close environment. They rely on simple stylistic devices, commonly found in children's poetry, such as repetition, anaphora, enumeration, onomatopoeia, which gives the text musicality, sonority and memorability. The author wants to attract the child to discover the world together, by using child-like imagination. In this way, she shows a child the basic relationships occurring in nature and in the world of objects, forms their worldview, affects his or her emotions, and thus strengthens the relationship with them. The poems teach about the world close to the child and have a stylistic function, containing diminutive phrases, adjectives, and word combinations that serve to communicate and evoke positive feelings. Some of them, e.g., "Bez-Beziko", "Un pasiko", "Dedikos palyachikos" and "Noche", could serve as action rhymes - poems to which specific gestures could be matched in order to entertain the child. Some of the pieces in the collection refer to games and toys for the youngest (balls, balloons, dolls, finger puppets).

The formal features and the range of vocabulary imply that Gattegno-Saltiel's poems could be effective material for learning Judeo-Spanish, both in private situations, where an adult provides the child's first contact with the language through 
shared reading and play, and in educational classes. Clearly, the poems can be also used as additional material in language lessons at beginner's level. The vocabulary is definitely dominated by nouns and adjectives, as the poems mainly consist of naming objects connected with the topic as well as adding to them a nominal or adjectival attribute. Nouns can be classified into the following groups: natural world, toys, fruits, clothes, objects from the close environment. Abstract nouns refer to names of colours or emotions. The largest group among the adjectives are the names of colours, basic physical properties and other adjectives of positive value. The syntax is very simple: in five poems out of twenty four there are no verbs at all, in four the only verb is ser (be), in the rest there are mainly ser and tener (have), and occasionally others such as cantar (sing), baylar (dance), riir (laugh).

The images in these poems are most often poetic descriptions of an object, state of affairs, or a situation familiar to the child and are constructed with components that engage the senses. Visual impressions dominate among them, and in this group - the variety of colours and light effects.

As an example, the poem "Blanka" (White) paints a seascape, reducing it to just a few objects and one dominant colour, and includes a reference to an emotional state in the final section:

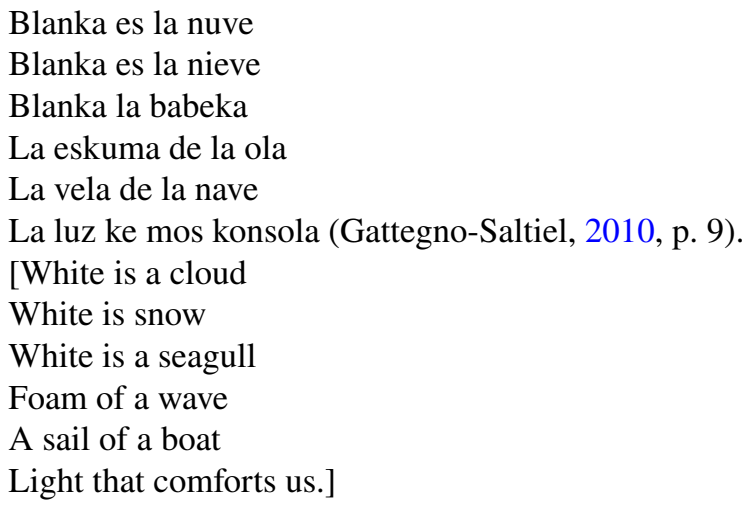

Three poems mention family members. In the last poem, it is the mother who takes part in preparing the child for bed in the evening (Gattegno-Saltiel, 2010, p. 30). In contrast, two others mention the grandfather, whose figure is associated with objects representing the past. These are also the only poems in which the past tense occurs. One of the objects is a golden watch pulled out of his pocket, the description of which becomes an opportunity to play with the false etymology of words (ora and oro, watch and gold in a poem "Ora de oro") and with onomatopoeic sound effects (tika-tika-tik, tiki-tiki-tak) (2010, p.18). In the second poem, the grandfather owns a Judeo-Spanish book, and this image as a whole redirects attention to the cultural heritage passed down through the older generation (2010, p. 8). The memory of this heritage still lingers in the family, and it can be signified by a valuable old object, but also by the language itself, which becomes the subject of this poem. Both the old watch and the book seem mysterious and arouse curiosity. The latter is particularly valuable - it has been described as a golden book (livro de oro), the letters in it are from the sun (letrikas del sol), and the words gleam in Judeo-Spanish. This imagery 
remains in dialogue with the special status that the book has always enjoyed in Jewish culture. Readers familiar with Judeo-Spanish folklore texts may also associate it with the traditional ditty rhyme for younger children: "La Torá, la Torá, / me se vaya a la heṿrá" ("Torah, Torah, / may you go to a religious school", see Weich-Shahak, 2001, p. 122).

The centrality of Judeo-Spanish in Multikolor is also underscored by the inclusion of its name in the collection's opening poem, which refers to the traditional formula spoken to relatives and friends on the occasion of Rosh ha-shanah, 5 "Anyada buena" meaning "Happy New Year" (Gattegno-Saltiel, 2010, p. 7). The juxtaposition of language with New Year's greetings, which are intended to point to the future, and with elements of the children's world that arouse curiosity and pleasant associations, places language itself in a positive context and shows its possible relationship to the present and the future. Thanks to this treatment, this volume avoids the nostalgic tone typical of most Judeo-Spanish poems of the last four decades and does not completely lock it into a past perspective.

\section{Poetry for Older Children in Avner Perez}

Avner Perez is a renowned researcher of Judeo-Spanish literature, its editor, and a translator from and into Hebrew. He is an author of two books of original poems in Judeo-Spanish (Siniza i Fumo, 1986; Verdjel de Mansanas, 1996) as well as of numerous short essays in Aki Yerushalayim magazine.

In contrast to Gattegno-Saltiel's Multikolor, conceived as poetry for the youngest, e.g. nursery and preschool age, Perez's Una Torre en Yerushalayim (A Tower in Jerusalem) follows the model of poetry for older children, aged five to twelve. Thus, both books appear to be complementary because they cover the needs of distinct age groups, whose aesthetic and intellectual satisfaction depends on gradual psychological, social, and cultural development (see Rubio Pérez, 1999, p. 30). The most visible dissimilarity is the length of the poems. The majority of Perez's compositions are much longer than Gattegno-Saltiel's, they are also based on more varied vocabulary and more advanced syntax. The poems in Una Torre en Yerushalayim contain vivid images and suggestive metaphors as well as a great variety of sound devices such as rhythm, alliteration, rhyme, repetition and onomatopoeia. These techniques are quite common in children's poetry and as such they do not make the project unique; nonetheless, they confirm the intention, declared in the preface, of testing and enhancing the literary potential of Judeo-Spanish in the genre of children's poetry.

The title of the book, which coincides with the title of the first poem, refers to a real place in Jerusalem, a structure called the Tower of David. It is a remnant of an Ottoman citadel, but its customary name evokes the ancient biblical history. Thanks to the introduction of this element, the entire volume seems to be rooted in

\footnotetext{
5 Rosh ha-shanah is a Jewish New Year celebrated in September or October depending on the liturgical calendar of a given year.
} 
Jerusalem, and both the city and Israel are shown as a natural contemporary space for cherishing Judeo-Spanish. The title poem ends with an image of a bird whose wail echoes from the tower every night. In the context of the Jewish history recalled here, this symbolic image can be interpreted as a lament for the predicaments of the Jews.

In other pieces, Perez raises diverse topics such as the beauty of natural phenomena and places, imaginary adventures that may happen to a child, a space journey, the aliya ${ }^{6}$ of his grandma to Jerusalem, short portraits, or stories of people. His volume contains poems of both lyric and narrative character. "Otonyo" (Autumn), one of the shortest verses, is an example of a lyric composition which describes with simplicity the beauty of this season of the year (see Perez, 2010, p. 11). By means of plain description and metaphor, it draws the reader's attention to a gorgeous autumn sky above a city. This poem can appeal equally to children and adults, which is not unusual since not always children's verse differs from 'adult verse' by "language, tone, form or style" (Grenby, 2008, p. 32). Only the author's intention of including it in a book of children's poetry makes it a poem for children.

"El aire" (The wind) represents a child's perspective - in this particular case on a situation that happened during a stroll.

Una flor amariya

en mi mano

yo tenia,

una flor ermozika

tenia

i la pedri

Indome

por el kaminiko

vidi saltar un saltamontiko

deshi la flor

i avagariko

kon la mano lo anferri.

[...] (Perez, 2010, p. 12).

[I had.

a yellow flower.

in my hand.

a lovely little flower.

I had.

and I have lost it.

While walking.

on the path.

I saw a little grasshopper,

I left the flower.

and very slowly.

\footnotetext{
${ }^{6}$ The term which refers to Jews' migration to the Land of Israel.
} 
I caught it with my hand].

A characteristic feature of this poem is its short, uneven lines that seem to imitate the pace of a child's walking and powers of sudden, close observation. An attempt to show a way in which little ones talk about the world can also be observed in the frequent use of diminutives as well as in the repetition of a few crucial words: "flor" and "la pedri", thus, the loss of a flower becomes the leading topic. The objects mentioned in the poem may be found on the ground in the real world, perhaps as a reflection of the line of vision of children, who more often than grown-ups look carefully at ground-level. Some texts are set in close reality, such as the city (presumably Jerusalem), the streets, the neighborhood, or in more distant places like a desert, Paris, or even the outer space. The map that the child explores through these poems thus covers places that are the scene of the child's daily routines, but also locations that are far away, seldom visited, even those whose names the child knows only by hearsay.

In several poems, Perez tries to capture the world with childlike imagination. Sometimes he does so by using the elements of fantasy, namely in "La luna vino al kortijo" [The moon came down to the courtyard] (Perez, 2010, p. 10), where some girls and boys see the moon descend towards them in a foggy dust and the youngest one enters it through a small door, then is taken up to the sky. This is a narrative poem with elements of dialogue achieving a poetic sense with the help of surprising images. Unusual images and rare associations are important means of expression in "Un ombre kita rizas" [A man pulling out handkerchieves] (Perez, 2010, pp. 22-23) and "Yair tiene un mestro ke le ambeza a ulvidar" [Yair has a teacher who teaches him to forget] (Perez, 2010, pp. 24-25). In the former, a play on words can be found because "rizas" signifies both handkerchiefs' and laughter. In "Ninguno" [No one] there is an intent to represent graphically, via the arrangement of lines, the content of the poem: an echo reverberating in an empty street.

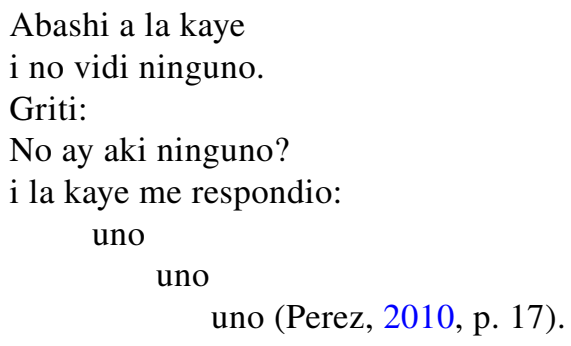

[I went out on the street.

and I saw no one.

I shouted:

Is there anyone?

And the street answered me:

one

one

one]. 
"La aliya de mi nona a la tierra santa (1876)" (Perez, 2010, p. 8-9) touches on the topic of roots and family history. The story of the arrival of the author's grandmother in Jerusalem for the first time is rendered in oneiric images of beauty, certain mystery, warmth, and goodness contrasting with the unknown or cold.

Generally, Perez's poetry intended for children is relatively varied as to the topics and formal aspects. It should be remembered that the volume contains poems which in the 1970s were first published in Hebrew in the children's magazine Davar li-Yeladim. In the 1980s, the author decided to translate them into JudeoSpanish. The common edition with Gattegno-Saltiel's book was prepared about twenty years later, in the time when Perez translated or co-translated into Ladino two other books widely considered belonging to the world canon of children's literature: El Princhipiko [The Little Prince] by Antoine Saint-Exupéry (Saint-Exupéry, 2010) and Las Aventuras de Alisia en el Paiz de las Maraviyas [Alice's Adventures in Wonderland] by Lewis Carroll (2014). The author understands a special role of translation as a means of enrichment of Judeo-Spanish in its current condition. Furthermore, his interest in translating children's literature into Judeo-Spanish can be recognized as a symbolic act of providing reading matter to the young generation, without which the improvement of the state of Sephardic language will be very difficult.

\section{Poetry and Music-Sarah Aroeste's Educational Books}

While it might seem that the postvernacular Judeo-Spanish community no longer needs children's literature, and that its publication has a purely symbolic value, 2016 has seen the emergence of a new proposal for contact with Sephardic language aimed at the very young. Its author is an American singer of the younger generation, Sarah Aroeste, who has already released albums in Ladino for an adult audience. She comes from a Sephardic-Ashkenazi family, where the Sephardic tradition from Macedonia was cultivated. Although her relatives no longer spoke Judeo-Spanish - as she puts it, "it was a typical story of immigrants from Europe"7 - the language was present through music. While searching for her own style and means of expression, she realized that if her work was to be authentic and reflect the experience of her generation, it could not be a literal re-creation of traditional music. Instead, she draws inspiration from cultural heritage of Spanish Jews more broadly, adding to it the styles that shaped her own musical sensibilities (funk, jazz, rock, etc.). She uses these references to convey content hidden in traditional music but important to her generation, such as social, feminist ideals of independence and self-determination.

Developing a project for children, she wrote the lyrics and music for the eleven songs that make up the album Ora de Despertar (Time to wake up, Aroeste, 2016). As for the subject matter, it covers the typical themes found in children's poetry: the

\footnotetext{
7 I obtained this information in my interview with Sarah Aroeste in December 2020. For more information see also Aroeste, 2021.
} 
sequence of times of the day and the routines associated with them, meals, parts of the body, the natural world, basic feelings, greetings used to make daily contacts, etc. Talking about the beginnings of this project, the singer recalls that she became interested in children's music when she was expecting a child herself. At that time, she was listening to and collecting recordings of music for children in various languages, especially Jewish ones. She realized then that Judeo-Spanish recordings for children were virtually non-existent. She was looking not for arrangements of old traditional music, but for texts that dealt with topics close to children's sensibilities. Since there was a gap on the discographic market, she created the lyrics herself to meet this demand. The songs in this project are available with accompanying animations on YouTube, and for the benefit of teachers, they have been published in the form of a songbook with lyrics in Ladino, English translation and musical notation (Aroeste, 2016).

The first of the songs in the collection was also published in two language versions in the form of a separate booklet with illustrations, in which one verse or chorus is placed separately on subsequent pages. The text of the song itself is preceded by a two-line Modeh Ani prayer, customarily said upon waking up to give thanks for a new beginning. The prayer is included in three language versions: English, JudeoSpanish, and Hebrew (the latter appears in the transcript in two alphabets - Hebrew and Latin). The book combines language education with an introduction to the customs of Judaism. As in the case of Perez's and Gattegno-Saltiel's publications, the Judeo-Spanish text is not given entirely on its own: it is supplemented by paratextual elements and translations of the poems in English. The publisher was aware that today the vast majority of potential readers - mainly grandparents, parents, or teachers who will either read these poems to children or sing them together - need the support of another language to understand Judeo-Spanish. Again a dual audience is at stake here. The adult not only buys the book or CD and reads or plays it to the child, but also translates the meaning from Judeo-Spanish into the child's language.

As for the structure of the songbook, it opens with a poem about waking up and closes with a song related to going to bed. There is also a song about meals and another that teaches the most common greeting, farewell, and salutation phrases. Songs such as "Mi famiya", "Kuantos animales", "Las manos", "Kualo tienes?" are primarily aimed at teaching vocabulary from a specific meaning group (family, animals, numbers, body parts, body activities, feelings) in combination with a selected phrase or verb construction, e.g., te kero bien (I love you so much), kualo tienes presiado? (What's up, honey?). On the other hand, "Komo vas a ser?" or "Si yo era el sielo" expand vocabulary, but their central element is the consolidation of a grammatical construction - expressing the future in the first case and the 2nd conditional mode in the second. Some poems follow the pattern of "list-making", quite common in contemporary children's books, as they contain catalogue of things or activities (see Lerer, 2008, p. 4-5). Language education proceeds through playin almost every song you can imagine a set of movements that can accompany its performance. For example, before the last song, there is a poem entitled "La riza" (Laughter), which has no words, only the clue Tiempo para riyir! (Time to laugh). This activity addresses the young participants' need for relaxation. 
Compared to Gattegno-Saltiel's poems addressed to the same age group, Aroeste's pieces are longer and have a more regular structure - strophic (from 3 to 10 stanzas), usually with a refrain. The form results from the adaptation of the work to perform the function of a song. They do not build any surprising and beautiful imagery - as is the case in Gattegno-Saltiel and Perez - but place words in simple contexts so as the child could remember the lexis, to consolidate it through repetition, and to connect it with music and play.

It is known that the project reaches out to the public. Aroeste conducts educational activities based on these materials, e.g., the Sephardic Brotherhood of America association commissioned her to conduct a series of meetings for children from families with Sephardic roots. She has also conducted classes for children from other backgrounds, e.g., from families who want for their children education about the diversity of Jewish culture. Her CDs and books are advertised on Jewish parenting websites, whose recipients are not only - as she herself put it - "white Ashkenazi parents" (my interview with Aroeste). The demand for such literature can be seen in the fact that a PAL Publisher decided to publish her next book: a board book Buen Shabat (Aroeste and Rubio, 2020), intended for infants up to three-year olds, which is written in English with isolated phrases and words in Judeo-Spanish. The author stresses that knowledge of Ladino is not particularly widespread, which is why there is a need for educational materials that inform about it and provide contact with elements of the language for both children and their parents. Aroeste outlined her motivation for this venture in the preface to the songbook:

Ora de despertar, or "time to wake up", is my way of helping to ensure that Ladino music and culture gets passed down to a new generation. [...] I wanted to leave a lasting legacy for my children and for other families searching for ways to keep Ladino alive for young ones. They are a "wake up call" for parents and the outside world, that we need to open our eyes and teach our children before it is too late (Aroeste, 2016, n.n.).

\section{Yeladino (ילאדינו)-Strengthening the Language by Translation}

Another new project also combines Judeo-Spanish with music in the form of recordings, and was prepared as a theatrical and musical performance for young audiences, which was presented at the HaBimah theatre in Tel Aviv. It is likely that this complex form, which aims to reach the audience through various channels, was chosen in view of the situation of an endangered language. The publisher and originator is the Autoridad Nasionala de Ladino i su Kultura (Ha-Rashut ha-Leumit le-Tarbut ha-Ladino), the most important cultural institution concerning Sephardic culture in Israel today. The publisher and authors have resorted to means that have not been used before for Sephardic poetry for children. The project consists of translations into JudeoSpanish of over thirty poems by Israeli authors of children's literature, such as Talmah Alyagon-Rose, Hayyim Naḥman Bialik, Leah Goldberg, Levin Kipnis, Miriam Yalan-Stekelis et al., collected in the two-volume collection Yeladino. ${ }^{8}$ In addition, the

\footnotetext{
${ }^{8}$ From this point I will use the Latin transcription of this title.
} 
Autoridad Nasionala de Ladino has released the Yeladino app in Hebrew, for interactive learning of Judeo-Spanish. The project thus encompasses much more than the poetry anthology itself. Linguistically, the title is a hybrid of two languages: Hebrew and Ladino, as it combines the name of the Sephardic language with the Hebrew noun ילד (yeled) meaning "child" in its plural form לדים (yeladim). This reflects the nature of the project, which starts from Hebrew-language culture in order to bring the audience closer to Judeo-Spanish. An anthology was translated by Shmuel Refael, a professor of Sephardic literature at Bar-Ilan University. In the afterword, he and one of the performers, Hani Nahmias, wrote that Israeli children's poetry accompanied them at an early age. It naturally became a resource that they as parents passed on to their children, who in turn continue to pass it on to their own. They note, however, that in their generation another voice co-created their first childhood contact with poetry - a voice of Sephardic Jewish heritage, which, as they write, gradually faded away in the childhood landscape of later generations (Yeladino 1, 2017, p. 34).

This item fills a gap in the market of children's books in this endangered language. New linguistic and literary material, together with its characteristic contemporary means of expression adapted to the needs of the audience - that is a new repertoire in Judeo-Spanish was being elaborated by means of translation (see Itamar Even-Zohar 1990, pp. 46-48). This is a typical situation for "weak" literary systems. In many different moments of the past, Sephardic literature was enriched by translation, however, the directions of transfer did change, (e.g., in the sixteenth and seventeenth century the main direction was from Hebrew into Judeo-Spanish, while in the nineteenth century from French (see Borovaya, 2012, pp. 139-165; Díaz-Mas, 2020, pp. 98-111). Nowadays, Judeo-Spanish is still a weak system, but more than ever it faces a deep crisis and literary vacuum due to its condition. The authors of Yeladino, who function primarily in Hebrew culture, started from that culture - from the classics of Israeli children's poetry (Yeladino 1, 2017, p. 34) - in order to bring the youngest children into contact with Judeo-Spanish. For some audiences, it is the language of their roots, while for others, it is one of the languages of the Diaspora that has historically contributed to the mosaic of Jewish cultures and traditions. In recent years, Israel has been emphasizing this diversity and showing its value, which is a new quality in relation to the language policy of the first decades after the establishment of the Jewish state. At that time, every effort was made to ensure that Hebrew was the dominant language in books and newspapers, especially for children, as well as in education, and that very good knowledge of Hebrew replaced the attachment to languages of the Diaspora. The idea was to establish Hebrew in the emerging Israeli society as a common tool of communication and participation in culture. This is why no Judeo-Spanish books for young readers were published in the 1950s and 1960s. That trend is also exemplified by the fact that there was no children's column in the only weekly newspaper published in the JudeoSpanish, El Tiempo. ${ }^{9}$ When the new magazine Aki Yerushalayim (published with varying regularity on an annual and semi-annual basis) was launched in 1978 after a tenyear break, there was no children's section. The only texts intended for this age group (inserted occasionally) were translations into Judeo-Spanish of Perez's Hebrew poems

\footnotetext{
${ }^{9}$ I would like to thank Susy Gruss for sharing this information.
} 
and selected texts by Gattegno-Saltiel, which later became, respectively, part of Una torre en Yerushalayim and Multikolor.

The poems in Yeladino are varied in subject matter and structure, although a strophic structure with a refrain generally prevails. They employ a wide range of stylistic devices typical of contemporary children's poetry, which have already been mentioned when discussing previous collections. In Yeladino, for example, there are forms based on dialogue; the repetition of syllable combinations, often in the nature of onomatopoeia, sometimes the syllable sequences coincide with the Hebrew original. There are narrative, descriptive, and lyrical pieces. As far as subject matter is concerned, there are songs for learning about the body and playing with body movements, emotions (pleasant and unpleasant, e.g. anger in "Ravia"), family members, states and elements of nature (rain, storm, plants, animals), objects from the world familiar to the child (hat, clock, ice cream, toothbrush and toothpaste), numbers, hobbies and games (playing instruments, riding a horse, driving a car). The characters are children, gnomes, animals, and toys. One poem may be regarded as cautionary as it teaches the habit of washing oneself before going to bed. Four songs can be considered occasional: two are about birthdays, while two are related to the customs of Judaism, i.e. Shabbat. In each of the four projects, alongside the universal themes of children's poetry, poems concerning Jewish culture - its customs or past - are included.

What Yeladino has in common with Aroeste's project is the combination of the text of the poem with music and the possibility of treating selected pieces as action rhymes. The anthology also shares with Perez's volume a rich vocabulary, a diversity of grammar, and a richer repertoire of syntactic constructions allowing more complex expressive content than in Gattegno-Saltiel and Aroeste. In addition, the number and selection of poems provide greater thematic and formal variety. On the song recordings, passages are sung in Hebrew alongside the Judeo-Spanish text, making the songs more understandable and familiar to Hebrew-speaking children. The first volume closes with a text in Hebrew, into which Judeo-Spanish equivalents of basic vocabulary words are woven. It bears the meaningful title "Himnon Yeladino" (המנון ילאדינו), which acts as the anthem of a children's land where ladino is spoken or sung: ${ }^{10}$

(Yeladino 1, 2017, p. 32).

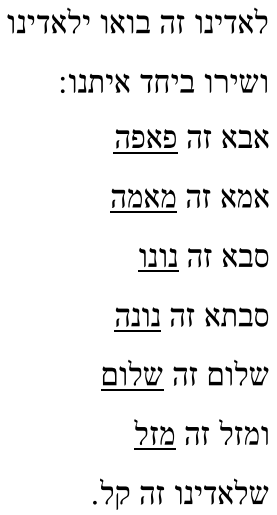

${ }^{10}$ In the lyrics and translation of this song the Ladino words are underlined. 
[Ladino is like: come yeladino

And sing together with us

Daddy is papa

Mummy is mama

Grandpa is nono

Grandma is nona.

Hello is shalom

Luck in mazal

Because Ladino is easy].

The last two words, whose Ladino equivalents are given in this refrain, constitute the common lexical resource of both languages. Presumably, this is meant to convince children that it will not be difficult to learn Sephardic speech. The piece conveys some cultural knowledge - for it emphasizes that the two languages share a common element, a Hebrew-Aramaic component that was historically very strong in Judeo-Spanish. In the current phase of the language's existence, researchers point out that it is becoming increasingly similar to modern Spanish, and that the vocabulary and morphological features derived from Hebrew, Turkish, Greek, South Slavic languages are being lost. In this song it is the Hebrew component that is highlighted. Moreover, it is not the only cultural element introduced in the "hymn" since the history and the most important features of the language are summarized in it. In Aroeste's books, the introduction of a basic historical context is also important, but it is presented in the preface aimed primarily at the adult audience, who can in turn pass it on to the child. "Himnon Yeladino" replaces the parent or teacher commentary to some extent, as it communicates to the children themselves some important messages about the past of the language they are singing in and about.

An interesting touch is also included at the end of Yeladino 2 - an old JudeoSpanish action rhyme, incorporated only in its original version. It is one of wellknown and widespread folk rhymes "Los dedos hambrientos" (Hungry Fingers), thirteen different variants of which (from informants coming from several places in the Turkish-Balkan and North African diaspora from Dupnitze in Bulgaria, to Thessaloniki in Greece, Izmir in Turkey, and Tetuan in Morocco) have been collected in the only existing anthology of traditional Sephardic children's poetry compiled by Susana Weich-Shahak (2001, pp. 181-184). In this way, the authors of Yeladino have symbolically emphasized their project's connection to the old Sephardic heritage. They also paid homage to this past and its role in their family history and identity.

\section{Conclusion}

In the old Sephardic community, the traditional children's repertoire, which includes poems, but also music and a good number of plays and habits related to the child's life and growth, played an important role (see Molho, 1950, pp. 131-144). A quick overview of this repertoire offers a possibility of appreciating its abundance and heterogeneity, allowing for the fact that the traditional compositions for children come 
from Hispanic medieval sources, but often incorporate contributions of the countries where Sephardim settled (see Susana Weich-Shahak, 2001; Ana Pelegrín, 2001). Obviously, children and adolescents also listened to folk texts not restricted to their age group, sung or told by adults in everyday and festive situations (e.g. Judeo-Spanish romances, ballads, or edifying read-alouds). In addition, the young boy in a religious school (meldar) encountered texts that were intended to support his religious education.

In general, modern children's literature did not develop in Judeo-Spanish literature because the demand for it emerged at a time when the national languages or languages of prestige became the languages of scholarity. It was in them that the young generation could read new literature. When, after decades of absence of JudeoSpanish from the publishing market, in the 1980s the first new works for children had begun to appear, their authors or translators into Judeo-Spanish were faced with the necessity of reinventing linguistic, formal and expressive means suitable for the youngest audience. To some extent they could find inspiration in Sephardic folk art. However, in order to meet the needs of contemporary children, they "transplanted" into Judeo-Spanish the patterns that had developed earlier in the literature of other languages, especially Hebrew and English. In this sense, this poetry is not a direct continuation of the ancient oral heritage, but instead follows contemporary literary trends.

In answer to the question: "For whom were the poems discussed in this article published?", two main target groups must be identified. It is well known that, in the postvernacular mode of Judeo-Spanish, there are no children who would constitute a natural audience as - the young readers are recruited from a group that primarily interacts with works in other languages. They are the possible audience. However, in order to bring them into contact with Judeo-Spanish, it is first necessary to convince the mature generation of people with Sephardic roots that it is worthwhile to provide their children or grandchildren with Judeo-Spanish texts. The primary goal of the publishers and authors was to offer these texts through which this contact would take place. In the Afterword they were referred to as a refreshing breath of air which will help guard the Judeo-Spanish heritage for the benefit of future generations (2017, p. 34). An additional goal is to enrich the history of Judeo-Spanish literature, to explore new ways of expression and communication in this language, as well as to prolong the existence of the language itself.

To sum up the issue of implied and real audience, on both these levels - i.e., the implied and the real - a dual address is at stake, which refers both to children and adults, as in many children's works in other languages, because "adults are always implicated in children's literature" (Bullen \& Nichols, 2011, p. 214) at various stages of its way to a real child audience. However, there is also more at stake in the case of Judeo-Spanish poetry - a young reader's encounter with this would absolutely not be possible without an adult given the latter's knowledge of the language itself. Without the adult's participation, children will not understand the text: in Perez's and Gattegno-Saltiel's cases, they will not even read it, while in Aroeste's project and in Yeladino, thanks to the CD recordings, they can only listen to it; however, in case of Yeladino the child will probably understand more, since the Judeo-Spanish and Hebrew fragments are intertwined. Here two of Gattegno-Saltiel's poems can be 
recalled again: an old grandfather's watch and a precious book with golden letters described in them become metaphors for Judeo-Spanish and its culture. Preserved by older generations, they may be seen, touched, experienced by a child who may get excited and attached to them. This will probably lead to other forms of engagement with the language in future. Both its memory and salvage depend on these first contacts with Judeo-Spanish, provided by parents, grand-parents and teachers.

Open Access This article is licensed under a Creative Commons Attribution 4.0 International License, which permits use, sharing, adaptation, distribution and reproduction in any medium or format, as long as you give appropriate credit to the original author(s) and the source, provide a link to the Creative Commons licence, and indicate if changes were made. The images or other third party material in this article are included in the article's Creative Commons licence, unless indicated otherwise in a credit line to the material. If material is not included in the article's Creative Commons licence and your intended use is not permitted by statutory regulation or exceeds the permitted use, you will need to obtain permission directly from the copyright holder. To view a copy of this licence, visit http://creativecommons.org/licen ses/by/4.0/.

\section{References}

Aroeste, Sarah. (2016). Ora de despertar. Original Ladino Songs for Children, illus. Elke Reva Sudin. N.p.: Aroeste Music.

Aroeste, Sarah. (2017). Ora de despertar. Time to Wake up, illus. Miriam Ross. N.p.: Aroeste Music.

Aroeste, Sarah, and Rubio, Ayesha L. (2020). Buen Shabat. Shabbat Shalom: Kar-Ben Publishing.

Aroeste, Sarah. (2021). Sarah Aroeste. Accessed February 5, 2021 from https://saraharoeste.com/home.

August-Zarębska, Agnieszka, and Paprocka, Natalia. (2021). Les enjeux de la traduction littéraire en langue périphérique et post-vernaculaire. Le cas du judéo-espagnol. Romanica Wratislaviensia LXVIII, 9-26.

Brink-Danan, Marcy (2011). The meaning of Ladino: the semiotics of an online speech community. Language \& Communication, 31(2), 107-118.

Borovaya, Olga. (2012). Modern Ladino Culture. Press, Belles Lettres, and Theater in the Late Ottoman Empire. Bloomington \& Indianapolis: Indiana University Press.

Bullen, Elizabeth, and Nichols, Susan (2011). Dual Audiences, Double Pedagogies: Representing Family Literacy as Parental Work in Picture Books. Children's Literature in Education, 42, 213-225.

Carroll, Lewis. (2014). Las Aventuras de Alisia en el Paiz de las Maraviyas. Trezladado al Ladino por Avner Perez. N.p.: Evertype, Cnoc Sceichín, Leac an Anfa, Cathair na Mart, Co. Mhaigh Eo, Éire.

Cheetham, Dominic (2013). Audience in Children's Literature. English Literature and Language, 49, 19-30.

Díaz-Mas, Paloma. (2020). Libros, Lecturas y Lectores Sefardies. Madrid: CSIC.

El Instituto Maale Adumim para la dokumentación de la lengua judea-española (ladino) y su cultura. (2009). Dos livros de poezias para ninyos en ladino. Accessed February 2, 2021 from http://folkm asa.org/av/migdall.htm.

Even-Zohar, Itamar (1990). Polysystem studies. Poetics Today, 11(1), 1-268.

Gattegno-Saltiel, Ada. (2010). Multikolor. Poemas Para Chikos i Grandes. Maale Adumim: Yeriot.

Grenby, Matthew O. (2008). Children's Literature. Edinburgh: Edinburgh University Press.

Lerer, Seth. (2008). Children's literature. A reader's history, from Aesop to Harry Potter. Chicago London: The University of Chicago Press.

Martín-Ortega, Elisa, and August-Zarębska, Agnieszka. (2017). Poesía infantil sefardí: de la tradición oral a las canciones de cuna contemporáneas. Ocnos. Revista de Estudios sobre lectura, 16(2), 50-59.

Molho, Michael. (1950). Usos y costumbres de los sefardíes de Salónica. Transl. F. Pérez Castro. MadridBarcelona: CSIC, Instituto Arais Montano. 
Pelegrín, Ana. (2001) Tuvo que contar cien y un año. Estudio crítico de Ana Pelegrín. In Susana Weich-Shahak, Repertorio tradicional infantil sefardí. Retahilas, juegos, canciones y romances de tradición oral (pp. 41-73). Madrid: Companía Literaria.

Perez, Avner. (1986). Siniza i Fumo. Yerushalayim: n.e.

Perez, Avner. (1996). Verdjel de Mansanas. Maale Adumim: Yeriot.

Perez, Avner. (2010). Una Torre en Yerushalayim. Maale Adumim: Yeriot.

PJ Library. (2021). Children's and Middle Grade Books that Mirror the Diversity of Jewish Communities. Accessed February 17, 2021 from https://pjlibrary.org/beyond-books/pjblog/june-2020/diverse-jewish-childrens-books.

Romero, Elena (2008). Historia y literatura. In Ricardo Izquierdo Hassán and Elena Romero Benito (Eds.), Iacob $M$, (pp. 155-192). Sefardíes: literatura y lengua de una nación dispersa. Cuenca: Ediciones de la Universidad de Castilla-La Mancha.

Rubio Pérez, Susana. (1999). Reflexiones sobre la literatura infantil. Educere Revista Venezolana De Educación, 6, 28-31.

Saint-Exupéry, Antoine. (2010). El Princhipiko. Trezladado del franzes al ladino por Avner Perez i Gladys Pimienta. Neckarsteinach: Edition Tintenfaß.

Sephiha, Haïm Vidal. ([1977] 1991). L'agonie des Judéo-espagnols. Paris: Éditions Entente.

Shandler, Jeffrey. (2006). Adventures in yiddishland postvernacular language and culture. Oakland: The University of California Press.

United Nations Educational, Scientific and Cultural Organization. (2017). UNESCO Atlas of the World's Languages in Danger. Accessed February 24, 2021 from http://www.unesco.org/languages-atlas/ index.php?hl=en\&page=atlasmap.

Wall, Barbara. (1991). The narrator's voice. The dilemma of children's fiction. New York: Palgrave Macmillan.

Weich-Shahak, Susana. (2001). Repertorio tradicional infantil sefardí Retahilas, juegos, canciones y romances de tradición oral. Madrid: Companía Literaria.

Yeladino 1. (2017). Yeladino. Shirei Yaldut Yisre'elit be-Targum le-Ladino. Transl. Shmuel Refael. Yerushalayim: Ha-Rashut ha-Leumit le-Tarbut ha-Ladino.

Yeladino 2. (2018). Yeladino 2. Od Shirei Yaldut Yisre'elit be-Targum le-Ladino. Transl. Shmuel Refael. Yerushalayim: Ha-Rashut ha-Leumit le-Tarbut ha-Ladino.

Publisher's Note Springer Nature remains neutral with regard to jurisdictional claims in published maps and institutional affiliations.

Agnieszka August-Zarębska is an assistant professor in the Taube Department of Jewish Studies at the University of Wrocław, Poland. She has a degree in Spanish Studies and wrote her PhD thesis on comparative Spanish and Polish poetry. In recent years her main research interests have focused on JudeoSpanish contemporary poetry. She also worked on contemporary editions of the early twentieth century Judeo-Spanish literature. In Wrocław, she teaches Judeo-Spanish language and Sephardic culture and literature. She is a member of the Centre for Research on Children's and Young Adult Literature of the University of Wrocław. 